Acyloxylation of 1-methoxycyclohex-1-ene and other enol ethers with dimethyl peroxydicarbonate

Kurt Schank*, Horst Beck, Susanne Pistorius, and Thomas Rapold

Fachrichtung 11.2 Organische Chemie der Universität des Saarlandes, D-66041 Saarbrücken, Germany

Dedicated to Professor Manfred Regitz on the occasion of his 60th birthday

Acyloxylation of different types of enol ethers (derived from aldehydes and ketones) by dimethyl peroxydicarbonate (DPDC) results in either addition to the double bond or in a formal replacement of an allylic hydrogen by a methoxycarbonyloxy group forming vicinal oxygenated hydrocarbons. 1,3-oxygenated products via monoacyloxylation could not be observed. The results with 1-methoxycyclohex-1-ene (19) are compared with copper(I)-salt catalyzed acyloxylations by means of tert. butyl peroxycarboxylates $\underline{\mathbf{2}}, \underline{\mathbf{b}}$.

Allylic hydrogens in alkenes are easily replaced by bromine via a $S_{R}$ reaction using N-bromosuccinimide (NBS) ${ }^{1)}$. Corresponding replacement of allylic hydrogen by acyloxy groups occurs with tert. butyl peroxycarboxylates $\underline{\mathbf{2}}$ in the presence of cuprous salts as electron-transfer-catalysts (ETC $)^{2)}$ during the Kharasch-Sosnovsky reaction ${ }^{3)}$ Whereas 1-halogenocycloalk-1-enes react with NBS via $S_{R}$ yielding 1,3-disubstitution products ${ }^{4)}$, the related 1-alkoxycycloalk-1-enes show 1,2-disubstitution (or addition) products ${ }^{5}$. In order to investigate whether the latter compounds would form 1,2- or 1,3-substitution products,

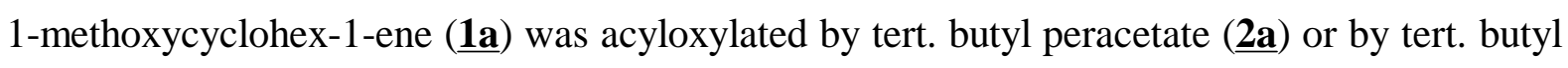

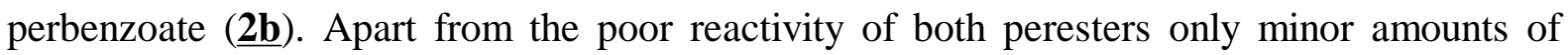
vicinal acyloxylation products (ㅈa: $11 \%, \underline{\mathbf{3 b}} 15 \%)$ were formed. The corresponding free carboxylic acids $\underline{\mathbf{4}}$ were main products ${ }^{6}$. The low yields of desired $\underline{\mathbf{3 a}}, \underline{\mathbf{b}}$ could not be enhanced in the presence of bases (potassium tert. butylate or calcium hydride). Therefore, DPDC $^{7)}$ was utilized as acyloxylating agent because elimination of methyl monocarbonate (4c) instead of a carboxylic acid would lead to carbon dioxide and methanol. Additionally, higher reactivity of $\underline{\mathbf{2 c}}$ compared with $\underline{\mathbf{2 a}}, \underline{\mathbf{b}}$ (as a consequence of a particularly low $\mathrm{O}, \mathrm{O}$ bond dissociation energy $\left.(\mathrm{BDE})^{8)}\right)$ should not need copper(I)-catalysis ${ }^{9)}$, enol ethers as electron rich olefins reacted spontaneously with $\underline{\mathbf{2}}^{10)}$. 


\section{Scheme 1:}

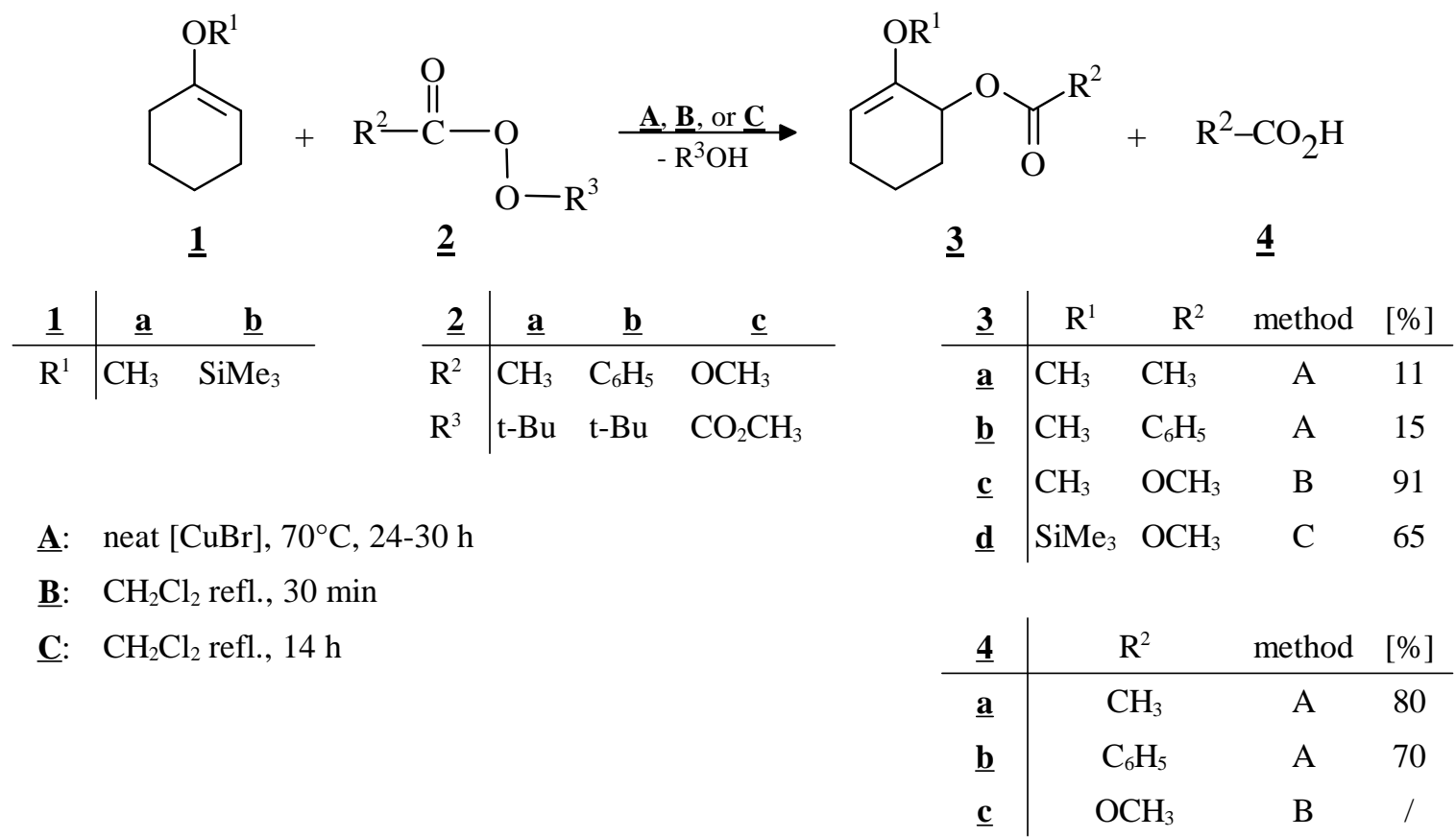

Since enol silyl ethers have been successfully acyloxylated by means of lead(IV)carboxylates $^{11)}$ the reactivity of $\underline{\mathbf{1 b}}$ toward $\underline{\mathbf{2}}$ compared with $\underline{\mathbf{1 a}}$ was checked. The reaction rate showed to be markedly slower ${ }^{12)} . \underline{\mathbf{3 c}}$ proved to be a rather attractive starting material for further conversions. Subsequent products were obtained via different standard methods: Thermolysis $\left(280^{\circ} \mathrm{C}\right.$, metal bath) led to methoxycyclohexadiene $\underline{\mathbf{5}}$, acid hydrolysis led to 2-(methoxycarbonyloxy)cyclohexanone $(\underline{\mathbf{6}})$, alkaline saponification led to 2-methoxycyclohex-2-en-1-ol () , and a second conversion with $\underline{\mathbf{2 c}}$ caused addition to the double bond with formation of $\underline{\mathbf{8}}$.

\section{Scheme 2:}<smiles>COC1=CC[C@H](C)C=C1</smiles><smiles>C#CC[C@@H]1CCC(OC(=O)OC)C(=O)C1</smiles><smiles>COC1=CCCCC1O</smiles>

7 $\underline{3 \mathbf{c}}$<smiles>COC(=O)OC1CCCC(OC(=O)OC)C1(OC)OC(C)=O</smiles>

$\underline{8}$

ㅁ: $280^{\circ} \mathrm{C}, 86 \%$; $: \mathrm{H}_{3} \mathrm{O}^{+}, 72 \%$; : $\mathrm{KOH} / \mathrm{CH}_{3} \mathrm{OH}, 76 \%$; : $\underline{\mathbf{3 c}}, \mathrm{CH}_{2} \mathrm{Cl}_{2} \mathrm{refl} ., 60 \%$ 
For structural proof $\underline{\mathbf{z}}$ was hydrolized by dilute mineral acid yielding the dimer of 2-hydroxycyclohexanone or was derivatized by means of benzoyl chloride/pyridine mixture yielding $\underline{\mathbf{3}}$; furthermore, $\underline{\mathbf{8}}$ has been utilized as primary product of a new synthesis for dihydro pyrogallol $\underline{12}$.

\section{Scheme 3:}

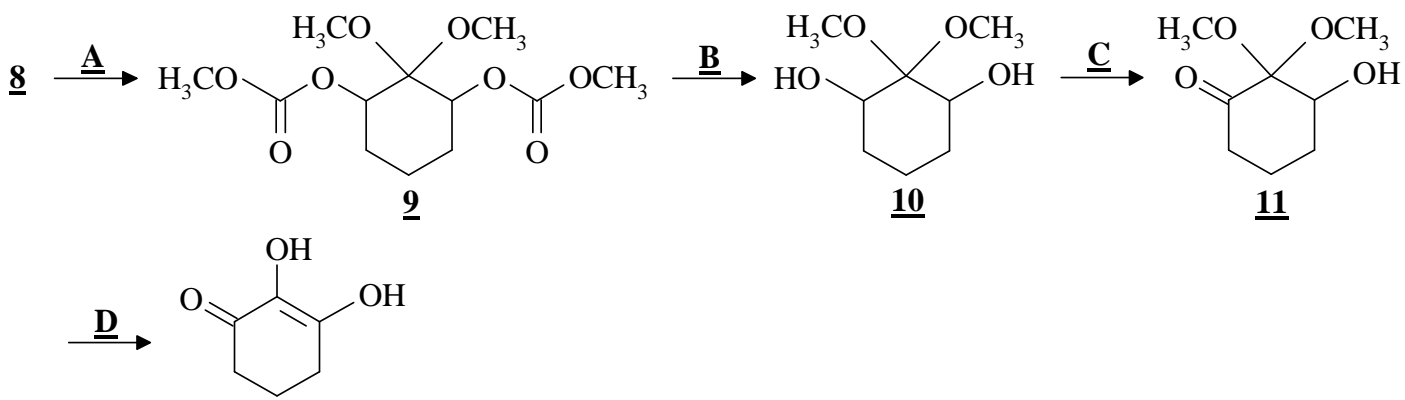

$\underline{12}$

ㅅ: $\mathrm{CH}_{2} \mathrm{Cl}_{2} / \mathrm{CH}_{3} \mathrm{OH}, 98 \%$; $\underline{\mathbf{B}}: \mathrm{KOH} / \mathrm{H}_{2} \mathrm{O}, \mathrm{CH}_{3} \mathrm{OH}, 50^{\circ} \mathrm{C}, 92 \%$; : $\mathrm{PCC}, \mathrm{CH}_{2} \mathrm{Cl}_{2}, 61 \% ; \underline{\mathbf{D}}: \mathrm{H}_{3} \mathrm{O}^{+}, 80^{\circ} \mathrm{C}, 75 \%$

$\underline{12}$ has not been isolated directly, the characteristic reducing properties have been confirmed qualitatively via positive ferric chloride and Tillmans tests ${ }^{13)}$, for quantitative determination highly water soluble $\underline{\mathbf{1 2}}$ was precipitated by lead(II)-acetate as its insoluble lead(II)-complex ${ }^{13)}$.

In order to gain more insight into enol ether - DPDC reactions further enol ethers have been subjected to this acyloxylation procedure. Ketone enol ethers $\underline{\mathbf{1 3 a}}, \underline{\mathbf{b}}, \underline{\mathbf{c}}$ (homologous to 1a) did not lead to exclusive formation of acyloxylated enol ethers $\underline{\mathbf{1 4}}$ as in the case of $\underline{\mathbf{1 a}}$. Methanol formed during the reactions was added in part $(\underline{\mathbf{1 5 a}}, \underline{\mathbf{c}})$ or completely $(\underline{\mathbf{1 5 b}})$ to the double bond yielding acyloxylated cycloalkanone dimethyl acetals $\underline{\mathbf{1 5 a}}, \underline{\mathbf{b}}, \underline{\mathbf{c}}$.

\section{Scheme 4:}<smiles>COC1=CCCCC1</smiles>

$\underline{13}$<smiles>COC1=CCCCC1OC(C)=O</smiles>

$\underline{14}$<smiles>COC1(OC)CCCCC1OC(C)=O</smiles>

$\underline{15}$

\begin{tabular}{c|ccc}
$\underline{\mathbf{1 3}}, \underline{\mathbf{1 4}}, \underline{\mathbf{1 5}}$ & $\underline{\mathbf{a}}$ & $\underline{\mathbf{b}}$ & $\underline{\mathbf{c}}$ \\
\hline $\mathrm{n}$ & 2 & 4 & 5
\end{tabular}

\begin{tabular}{c|c|c}
$\underline{\mathbf{1 4}}+\underline{\mathbf{1 5}}$ & {$[\%]$} & ratio $\underline{\mathbf{1 4}}: \underline{\mathbf{1 5}}$ \\
\hline$\underline{\mathbf{a}}$ & $55^{*)}$ & $57: 43$ \\
$\underline{\mathbf{b}}$ & $63^{* *)}$ & $0: 100$ \\
$\underline{\mathbf{c}}$ & 81 & $65: 35$
\end{tabular}

*) large amounts of polymeric by-products

**) $3 \%$ bis-acyloxylation product in analogy to $\underline{\mathbf{8}}$ during 1:1 conversion 
Pure enol ethers $\underline{14 b}, \underline{\mathbf{c}}$ could be finally obtained from their corresponding acetals $\underline{\mathbf{1 5 b}}, \underline{\mathbf{c}}$ by diphenylphosphinic acid catalyzed elimination of methanol at $140^{\circ} \mathrm{C}$ whereas $\underline{\mathbf{1 5 a}}$ suffered resinification under these conditions. Further acyloxylations of $\underline{\mathbf{1 4 a}-\mathbf{c}}$ were possible, however, these conversions led to crude mixtures of stereomers and other products. Vinyl and vinylene ethers $\underline{\mathbf{1 6}}, \underline{\mathbf{1 7}}, \underline{\mathbf{1 8}}$ (i.e. enol ethers from aldehydes) suffered exclusive addition of $\underline{\mathbf{2 c}}$ to their double bonds yielding $\underline{\mathbf{1 9}}, \underline{\mathbf{2 0}}, \underline{\mathbf{2 1}} . \underline{\mathbf{2 0}}, \underline{\mathbf{2 1}}$ appeared as mixtures of diastereomers.

\section{Scheme 5:}<smiles>[Y9]/C=C\O[R]</smiles>

$\underline{16}, \underline{17}, \underline{18}$

\begin{tabular}{l|cc} 
& $\mathrm{R}^{4}$ & $\mathrm{R}^{5}$ \\
\hline$\underline{\mathbf{1 6}}, \underline{\mathbf{1 9}}$ & $\mathrm{i}-\mathrm{C}_{4} \mathrm{H}_{9}$ & $\mathrm{H}$ \\
$\underline{\mathbf{1 7}}, \underline{\mathbf{2 0}}$ & $-\left(\mathrm{CH}_{2}\right)_{2}-$ \\
$\underline{\mathbf{1 8}}, \underline{\mathbf{2 1}}$ & $-\left(\mathrm{CH}_{2}\right)_{3}-$
\end{tabular}

$\underline{19}, \underline{20}, \underline{21}$

$\underline{\text { A: }} \mathrm{CH}_{2} \mathrm{Cl}_{2}$, bath of $50^{\circ} \mathrm{C}, 36 \mathrm{~h}$; $\left.{ }^{*}\right)$ a bath of $70-80^{\circ} \mathrm{C}$ gave rise to $57 \%$ methoxycarbonyloxyacetaldehyde i-butyl methyl acetal instead of $\underline{\mathbf{1 9}}$

Mechanistic Proposal.

It is suggested that formation of carboxylic acids $\underline{\mathbf{4}}$ as elimination products on the one hand and formation of desired enol ethers $\underline{\mathbf{3}}$ as substitution products of acyloxylations of $\underline{\mathbf{1 a}}$ by $\underline{\mathbf{2}}$, b under Kharasch-Sosnovsky conditions on the other hand are due to the intermediacy of two different isomeric methoxy allylic cations.

\section{Scheme 6:}

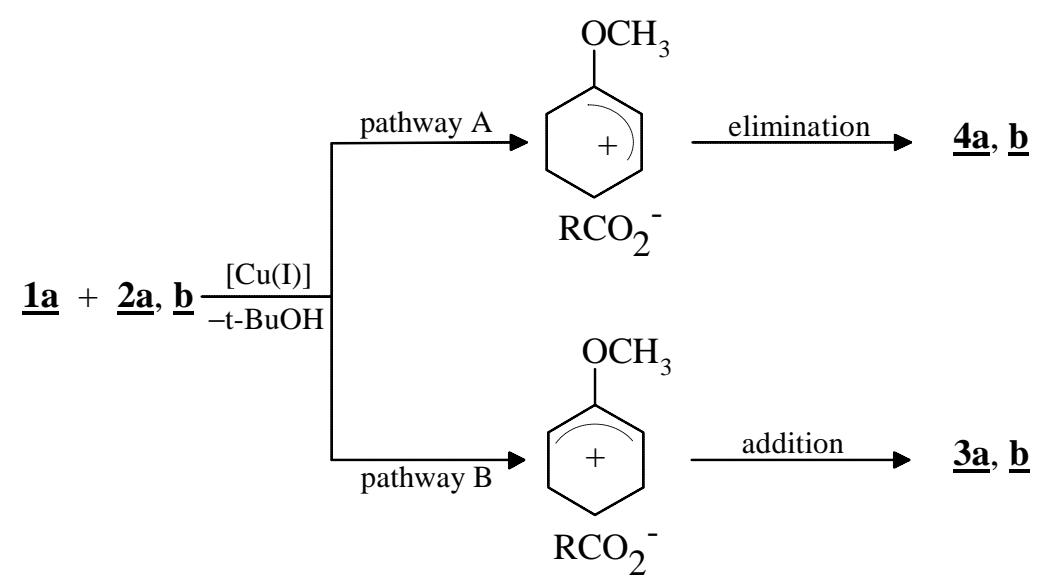


Pathway A would accord to the Kharasch-Sosnovsky mechanism ${ }^{3,14)}$ i.e. a radical hydrogen abstraction in the first step would be followed by oxidation of the resulting 1-methoxyallyl radical to its cation by copper(II), except that the last step would be an elimination of carboxylic acids $\underline{4}$ instead of ester formation via carboxylate addition. The first step of pathway $\mathrm{B}$ is suggested to be the consequence of an one-electron oxidation of electron rich enol ether $\underline{1 a}$ to its cation radical (cf. olefin radical cation formations ${ }^{15}$ ) followed by deprotonation to give a 2-methoxyallyl radical which is oxidized to its cation. The higher oxidizing power of DPDC compared with peresters $\underline{\mathbf{2}} \mathbf{\mathbf { a }}, \underline{\mathbf{b}}$ was obviously sufficient to cause an uncatalyzed SET ${ }^{16)}$ with enol ethers, therefore reactions of $\underline{\mathbf{1 a}}, \underline{\mathbf{b}}$ with $\underline{\mathbf{2 c}}$ should follow pathway B even without copper(I)-catalysis (addition of copper(I)-salt neither influenced the course nor the rate of the reaction). Since aldehyde enol ethers $\underline{\mathbf{1 6}} \underline{\mathbf{1 8}}$ are unable to form 2-alkoxyallyl cations they suffer direct addition of $\underline{\mathbf{2 c}}$ to the double bond ${ }^{17)}$.

Melting points are determined by means of a Fus-O-mat (Heraeus) or a copper block, IR spectra are recorded on a Beckman IR-33 (films or KBr-pellets), NMR spectra are recorded on Varian EM360, Bruker WP80 or AM400 spectrometers (solutions in $\mathrm{CDCl}_{3}$ with TMS as internal standard), elemental analyses are obtained from a Carlo Erba analyzer. TLC control of reaction mixtures are carried out using foils Alugram ${ }^{\circledR}$ SIL $\mathrm{G} / \mathrm{UV}_{254}$ from Macherey and Nagel. The following compounds are prepared according to known procedures: 1-Methoxy-1-cycloalkenes $\underline{\mathbf{1 a}}, \underline{\mathbf{1 3 a}} \underline{-}^{18)}$, in particular $\underline{\mathbf{1 a}}^{19)}$, 1-trimethylsiloxy-1-cyclohexene $(\underline{\mathbf{1 b}})^{20)}$, dimethyl peroxy-dicarbonate $(\underline{\mathbf{2}})^{21)}$. Other reagents used are commercially available. t-Butyl peroxyesters $\underline{\mathbf{2}}, \underline{\mathbf{b}}$ are dried prior to use according to a known procedure ${ }^{22)}$.

Caution: All handling with peroxy compounds is carried out behind a safety shield in a hood. Concentration of reaction mixtures presupposes decomposition of unreacted peroxide by boiling with cuprous chloride. No explosions are observed following this procedure.

Acyloxylations of $\underline{\mathbf{1 a}}$ with $\underline{\mathbf{2}}$ under Kharasch-Sosnovsky conditions: 1-Methoxy-1-cyclohexene (1a) $(56 \mathrm{~g}, 0.5 \mathrm{~mol}$ resp. $136 \mathrm{~g}, 1.2 \mathrm{~mol})$ and a catalytic amount of cuprous bromide $(0.5 \mathrm{~g}$

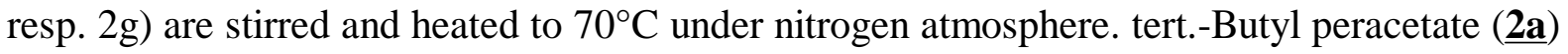
$(30 \mathrm{~g}, 0.22 \mathrm{~mol})$ resp. tert.-butyl perbenzoate $(\underline{\mathbf{2 b}})(97 \mathrm{~g}, 0.5 \mathrm{~mol})$ are added dropwise, and stirring is continued at $70^{\circ} \mathrm{C}$ until the deep blue color disappears (ca. $44 \mathrm{~h}$ resp. $30 \mathrm{~h}$ ). The cooled reaction mixture is diluted with twice of its volume of ether, copper salts are removed by filtration, and acetic resp. benzoic acid are extracted with aqueous potassium carbonate and determined acidimetrically; yields $80 \%$ resp. $70 \%$. The organic layer is dried with $\mathrm{MgSO}_{4}$ and separated under usual distillation conditions: 
Table 1: Data of $\underline{3 a}$ and $\underline{3 b}$

\begin{tabular}{|c|c|c|c|c|l|}
\hline & Yield [\%] & b.p.0.001 $\left.{ }^{\circ} \mathrm{C}\right]$ & \multicolumn{2}{|c|}{ IR $\left[\mathrm{cm}^{-1}\right]$} & \multicolumn{1}{|c|}{${ }^{1} \mathrm{H}-\mathrm{NMR}[\delta \mathrm{ppm}, \mathrm{TMS}$ internal] (Varian EM360) } \\
\hline 3a & 11 & 62 & $\begin{array}{c}\mathrm{C}=\mathrm{C} \\
1625\end{array}$ & $\begin{array}{c}\mathrm{C}=\mathrm{O} \\
1740\end{array}$ & $\begin{array}{l}1.9\left(\mathrm{~m}, 6 \mathrm{H}, 3 \mathrm{CH}_{2}\right) ; 2.1\left(\mathrm{~s}, 3 \mathrm{H}, \mathrm{CH}_{3} \mathrm{CO}\right) ; 3.52 \\
\left(\mathrm{~s}, 3 \mathrm{H}, \mathrm{OCH}_{3}\right) ; 4.95(\mathrm{~m}, 1 \mathrm{H}, \mathrm{CH}-\mathrm{vinyl}) ; 5.35 \\
\left(\mathrm{~m}, 1 \mathrm{H}, \mathrm{CHOCOCH}_{3}\right) .\end{array}$ \\
\hline$\underline{\mathbf{3 b}}$ & 15 & 88 & 1665 & 1715 & $\begin{array}{l}1.9\left(\mathrm{~m}, 6 \mathrm{H}, 3 \mathrm{CH}_{2}\right) ; 3.52\left(\mathrm{~s}, 3 \mathrm{H}, \mathrm{OCH}_{3}\right) ; 4.9 \\
(\mathrm{~m}, 1 \mathrm{H}, \mathrm{CH}-\mathrm{vinyl}) ; 5.6\left(\mathrm{~m}, 1 \mathrm{H}, \mathrm{CHOCOC}_{6} \mathrm{H}_{5}\right) ; \\
7.45,8.1\left(2 \mathrm{~m}, 3+2 \mathrm{H}, \mathrm{CH}_{\mathrm{ar}}\right)\end{array}$ \\
\hline
\end{tabular}

Hydrolysis of $\underline{\mathbf{3 b}}$ by refluxing a $\mathrm{CH}_{2} \mathrm{Cl}_{2}$ solution with $6 \mathrm{~N}$ aqueous hydrochloric acid for $2 \mathrm{~h}$ afforded 2-benzoyloxycyclohexanone, m.p. $84^{\circ} \mathrm{C}\left(\right.$ m.p. $\left.82-84^{\circ} \mathrm{C}^{23)}\right), 82 \%$ yield.

Mono- and bis-acyloxylation of 1a with DPDC (2c) and subsequent conversions of the resulting reaction products. a) Preparation of a solution of $\underline{\mathbf{2}}^{24}$ : Water $(200 \mathrm{~mL})$ is added to a mixture of methyl chloroformate $(37.8 \mathrm{~g}, 0.4 \mathrm{~mol})$ and $\mathrm{CH}_{2} \mathrm{Cl}_{2}(300 \mathrm{~mL})$ in a $2 \mathrm{~L}$ beaker. After cooling to $5^{\circ} \mathrm{C}$ (ice bath) sodium peroxide $(17.2 \mathrm{~g}, 0.22 \mathrm{~mol})$ is added in small portions under vigorous mechanical stirring, while the temperature does not exceed $10^{\circ} \mathrm{C}$. Stirring is continued for $2 \mathrm{~h}$ under further cooling, finally the two liquid phases are separated. The organic phase is washed with ice water and dried over $\mathrm{K}_{2} \mathrm{CO}_{3}$ at $0^{\circ} \mathrm{C}$ for $2 \mathrm{~h}$. Iodometric titration of an aliquot part indicates a yield of ca. $66 \%(20 \mathrm{~g}, 0.14 \mathrm{~mol}) \underline{\mathbf{6}}$. b) General acyloxylation procedure: 1-Methoxy-1-cycloalkenes $\underline{\mathbf{1 a}}, \underline{\mathbf{1 3 a}}-\underline{\mathbf{c}}(0.1 \mathrm{~mol})$ in dry $\mathrm{CH}_{2} \mathrm{Cl}_{2}(50 \mathrm{~mL})$ are heated to gentle reflux. Equimolar amounts of freshly prepared peroxydicarbonate $\underline{\mathbf{2 c}}$ in $\mathrm{CH}_{2} \mathrm{Cl}_{2}$ are added dropwise under stirring. Complete conversions need further stirring under these conditions, $30 \mathrm{~min}$ in the case of $\underline{1 \mathrm{a}}, 12 \mathrm{~h}$ in cases of $13 \mathbf{a}$ and $\underline{\mathbf{1 3 b}}$; in the case of $\underline{\mathbf{1 3} \mathbf{c}}$ the mixture must be stirred for $12 \mathrm{~h}$ under rather vigorous reflux. 13a $(11.9 \mathrm{~g}, 0.122 \mathrm{~mol})$ yields $12.27 \mathrm{~g}(55 \%)$ of a $57: 43-$ mixture of $14 \mathbf{a}$ and $\underline{\mathbf{1 5 a}}$, b.p. $55^{\circ} \mathrm{C} / 10^{-3}$ Torr; $\underline{\mathbf{1 a}}(16.8 \mathrm{~g}, 0.15 \mathrm{~mol})$ yields $22.2 \mathrm{~g}(91 \%)$ of $\mathbf{3 c}$, b.p. $78^{\circ} \mathrm{C} / 10^{-3}$ Torr; $\underline{\mathbf{1 3 b}}(12.62 \mathrm{~g}, 0.1 \mathrm{~mol})$ yields $14.6 \mathrm{~g}(63 \%)$ of 15b, b.p. $78-90^{\circ} \mathrm{C} / 10^{-3}$ Torr; diphenyl phosphinic acid $(100 \mathrm{mg})$ catalyzed elimination of methanol at $140^{\circ} \mathrm{C}$ from $\underline{\mathbf{1 5 b}}(13.6 \mathrm{~g}, 0.06 \mathrm{~mol})$ yields $7.81 \mathrm{~g}(65 \%)$ of $\underline{\mathbf{1 4 b}}$, b.p. $57-61^{\circ} \mathrm{C} / 10^{-3}$ Torr. $\underline{\mathbf{1 3 c}}(14.03 \mathrm{~g}, 0.1 \mathrm{~mol})$ yields $18.3 \mathrm{~g}(81 \%)$ of a $65: 35$ mixture of $\underline{\mathbf{1 4 c}}$ and $\underline{\mathbf{1 5 c}}$, which is immediately treated in the same manner as before to give $16.47 \mathrm{~g}(77 \%)$ pure 14c, b.p. $71-75^{\circ} \mathrm{C} / 10^{-3}$ Torr. 
Table 2: Spectral data of enol ethers 14a, 3a, 14b, 14c and corresponding acetals $\underline{15}$

\begin{tabular}{|c|c|c|c|c|}
\hline Product & IR, v & $\left(\mathrm{cm}^{-1}\right)$ & ${ }^{1} \mathrm{H}$ NMR, $\delta$ & ${ }^{13} \mathrm{C}$ NMR, $\delta$ \\
\hline$\underline{14 a}$ & $\begin{array}{l}C=C \\
1655\end{array}$ & $\begin{array}{l}\mathrm{C}=\mathrm{O} \\
1750\end{array}$ & $\begin{array}{l}1.70-2.51\left(\mathrm{~m}, 4 \mathrm{H}, \mathrm{CH}_{2}-\mathrm{CH}_{2}\right) ; 3.64(\mathrm{~s}, 3 \mathrm{H}, \\
\left.\mathrm{OCH}_{3}\right) ; \\
3.78\left(\mathrm{~s}, 3 \mathrm{H}, \mathrm{CO}_{2} \mathrm{CH}_{3}\right) ; 4.82(\mathrm{~m}, 1 \mathrm{H}, \mathrm{CH}-\mathrm{O}) ; \\
5.44 \\
(\mathrm{~m}, 1 \mathrm{H}, \mathrm{CH}=\mathrm{C})\end{array}$ & $\begin{array}{l}29.5,30.6\left(\mathrm{CH}_{2}\right) ; 54.6\left(\mathrm{OCH}_{3}\right) ; 57.1 \\
\left(\mathrm{CO}_{2} \mathrm{CH}_{3}\right) ; 80.9(\mathrm{CH}-\mathrm{O}) ; 109.7(\mathrm{CH}=\mathrm{C}) ; \\
155.3(\mathrm{C}=\mathrm{C}-\mathrm{O}) ; 156.9(\mathrm{C}=\mathrm{O})\end{array}$ \\
\hline$\underline{15 a}$ & & 1.750 & $\begin{array}{l}1.70-2.51\left(\mathrm{~m}, 6 \mathrm{H}, 3 \mathrm{CH}_{2}\right) ; 3.25,3.27(2 \mathrm{~s}, 6 \\
\left.\mathrm{H}, 2 \mathrm{OCH}_{3}\right) ; 3.79\left(\mathrm{~s}, 3 \mathrm{H}, \mathrm{CO}_{2} \mathrm{CH}_{3}\right) ; 4.91(\mathrm{~m}, \\
1 \mathrm{H}, \mathrm{CH}-\mathrm{O})\end{array}$ & $\begin{array}{l}\text { 19.1, 26.1, } 29.2\left(\mathrm{CH}_{2}\right) ; 48.7,50.7\left(\mathrm{OCH}_{3}\right) ; \\
54.6\left(\mathrm{CO}_{2} \mathrm{CH}_{3}\right) ; 78.5(\mathrm{CH}-\mathrm{O}) ; 100.3 \\
\left(\mathrm{C}_{\text {quart. }}\right) ; 155.7(\mathrm{C}=\mathrm{O})\end{array}$ \\
\hline${\underline{3 c^{a)}}}^{a}$ & 1665 & 1740 & $\begin{array}{l}1.40-2.20\left(\mathrm{~m}, 6 \mathrm{H}, 3 \mathrm{CH}_{2}\right) ; 3.53(\mathrm{~s}, 3 \mathrm{H}, \\
\left.\mathrm{OCH}_{3}\right) ; 3.85\left(\mathrm{~s}, 3 \mathrm{H}, \mathrm{CO}_{2} \mathrm{CH}_{3}\right) ; 4.8-4.95(\mathrm{~m}, \\
1 \mathrm{H}, \mathrm{CH}-\mathrm{O}) ; 5.05-5.20(\mathrm{~m}, 1 \mathrm{H}, \mathrm{CH}=\mathrm{C})\end{array}$ & \\
\hline$\underline{14 \mathrm{~b}}$ & 1665 & 1750 & $\begin{array}{l}1.50-2.0\left(\mathrm{~m}, 8 \mathrm{H}, 4 \mathrm{CH}_{2}\right) ; 3.47\left(\mathrm{~s}, 3 \mathrm{H}, \mathrm{OCH}_{3}\right) ; \\
4.79\left(\mathrm{~s}, 3 \mathrm{H}, \mathrm{CO}_{2} \mathrm{CH}_{3}\right) ; 4.90(\mathrm{t}, 1 \mathrm{H}, \mathrm{CH}-\mathrm{O}) ; \\
5.24(\mathrm{~m}, 1 \mathrm{H}, \mathrm{CH}=\mathrm{C})\end{array}$ & $\begin{array}{l}\text { 23.3, 24.2, 26.4, } 29.1\left(\mathrm{CH}_{2}\right) ; 54.4\left(\mathrm{OCH}_{3}\right) ; \\
78.1(\mathrm{CH}-\mathrm{O}) ; 100.4(\underline{\mathrm{C}}=\mathrm{C}) ; 155.1 \\
(\mathrm{C}=\underline{\mathrm{C}}-\mathrm{O}) ; 156.8(\mathrm{C}=\mathrm{O})\end{array}$ \\
\hline$\underline{15 b}$ & & 1750 & $\begin{array}{l}1.47-1.74\left(\mathrm{~m}, 6 \mathrm{H}, 3 \mathrm{CH}_{2}\right) ; 1.75-1.84(\mathrm{~m}, 4 \mathrm{H}, \\
\left.2 \mathrm{CH}_{2}\right) ; 3.18,3.22\left(2 \mathrm{~s}, 6 \mathrm{H}, 2 \mathrm{OCH}_{3}\right) ; 3.79(\mathrm{~s}, \\
\left.3 \mathrm{H}, \mathrm{CO}_{2} \mathrm{CH}_{3}\right) ; 5.46(\mathrm{~m}, 1 \mathrm{H}, \mathrm{CH}-\mathrm{O})\end{array}$ & $\begin{array}{l}20.2,20.4,25.9,26.5,30.8\left(\mathrm{CH}_{2}\right) ; 48.0 \\
\left(\mathrm{OCH}_{3}\right) ; 54.2\left(\mathrm{CO}_{2} \mathrm{CH}_{3}\right) ; 76.4(\mathrm{CH}-\mathrm{O}) ; \\
102.4\left(\mathrm{C}_{\text {quart. }}\right) ; 155.1(\mathrm{C}=\mathrm{O})\end{array}$ \\
\hline$\underline{14 c}$ & 1670 & 1755 & $\begin{array}{l}1.31-1.80\left(\mathrm{~m}, 10 \mathrm{H}, 5 \mathrm{CH}_{2}\right) ; 3.53(\mathrm{~s}, 3 \mathrm{H} \\
\left.\mathrm{OCH}_{3}\right) ; 3.77\left(\mathrm{~s}, 3 \mathrm{H}, \mathrm{CO}_{2} \mathrm{CH}_{3}\right) ; 4.70(\mathrm{t}, 1 \mathrm{H} \\
\mathrm{CH}-\mathrm{O}) ; 5.52(\mathrm{t}, 1 \mathrm{H}, \mathrm{CH}=\mathrm{C})\end{array}$ & $\begin{array}{l}23.5,24.3,26.5,31.5,33.1\left(\mathrm{CH}_{2}\right) ; 54.4 \\
\left(\mathrm{OCH}_{3}\right) ; 54.5\left(\mathrm{CO}_{2} \mathrm{CH}_{3}\right) ; 73.9(\mathrm{CH}-\mathrm{O}) ; \\
97.4(\underline{\mathrm{CH}}=\mathrm{C}) ; 153.0(\mathrm{C}=\underline{\mathrm{C}}-\mathrm{O}) ; 155.1 \\
(\mathrm{C}=\mathrm{O})\end{array}$ \\
\hline$\underline{15 c}$ & & 1.755 & $\begin{array}{l}1.20-2.58\left(\mathrm{~m}, 12 \mathrm{H}, 6 \mathrm{CH}_{2}\right) ; 3.20,3.22(2 \mathrm{~s}, \\
6 \mathrm{H}, 2 \mathrm{OCH} 3 ; 3.77\left(\mathrm{~s}, 3 \mathrm{H}, \mathrm{CO}_{2} \mathrm{CH}_{3}\right) ; 4.84(\mathrm{t}, \\
1 \mathrm{H}, \mathrm{CH}-\mathrm{O})\end{array}$ & \\
\hline
\end{tabular}

a) $\mathrm{C}_{9} \mathrm{H}_{14} \mathrm{O}_{4}(186.2)$ calc. $\mathrm{C} 58.05 \mathrm{H} 7.58$ found $\mathrm{C} 57.91 \mathrm{H} 7.59$

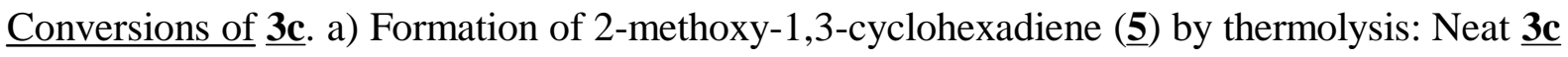
$(10 \mathrm{~g}, 0.054 \mathrm{~mol})$ is heated under nitrogen in a distillation apparatus of trimethylsilylated glass ware using a metal bath of $280^{\circ} \mathrm{C}$. The resulting distillate is dropped onto potassium hydroxide pellets under ice cooling. After filtration the crude distillate is fractionated i. vac. yielding 5.1g (86\%) $\underline{\mathbf{5}}$, b.p. $26^{\circ} \mathrm{C} / 10^{-3}$ Torr. b) Acid hydrolysis of $\underline{\mathbf{3 c}}$ yielding 2-methoxycarbonyloxycyclohexanone $(\underline{\mathbf{6 c}})$ : $\underline{\mathbf{3 c}}(9.3 \mathrm{~g}, 0.05 \mathrm{~mol})$ in $\mathrm{CH}_{2} \mathrm{Cl}_{2}(50 \mathrm{~mL})$ is heated to reflux with conc. hydrochloric acid $(15 \mathrm{~mL})$ and water $(15 \mathrm{~mL})$ for $30 \mathrm{~min}$. After cooling the organic layer is separated, washed with water and aqueous $\mathrm{NaHCO}_{3}$ solution and dried with $\mathrm{MgSO}_{4}$. After evaporation of the solvent, the residual oil is scratched with a glass bar after addition of a few drops of ethyl acetate yielding colorless crystals of $\underline{\mathbf{6 c}}, 6.2 \mathrm{~g}(72 \%)$, m.p. $65^{\circ} \mathrm{C}$ (ethyl acetate). c) Alkaline hydrolysis of $\underline{\mathbf{3 c}}$ yielding 2-methoxy-2-cyclohexen-1-ol (ㅍ): $\underline{\mathbf{3 c}}$ (40g, $0.215 \mathrm{~mol})$ and a saturated solution of $\mathrm{KOH}$ in methanol are stirred for $30 \mathrm{~min}$ at R.T. Methanol is evaporated and the residue is extracted continuously with ether for $10 \mathrm{~h}$. Distillation of the ether extract, finally i. vac., afforded $20.4 \mathrm{~g}$ (76\%) $\underline{7}$ as colorless liquid, b.p. $87-88^{\circ} \mathrm{C} / 13$ Torr 
$\left(92-98^{\circ} \mathrm{C} / 15\right.$ Torr $\left.^{24)}\right)$. $\underline{\mathbf{7}}(1.3 \mathrm{~g}, 0.01 \mathrm{~mol})$ in pyridine $(3 \mathrm{~mL})$ is benzoylated with benzoylchloride $(1.4 \mathrm{~g}, 0.01 \mathrm{~mol})$ at R.T. for $18 \mathrm{~h}$. After usual work-up, microdestillation affords $1.85 \mathrm{~g}(79 \%) \underline{\mathbf{3 b}}$ (cf. aforementioned data). For an additional proof $\underline{\mathbf{7}}$ (5.1g, $0.04 \mathrm{~mol})$ in $\mathrm{CH}_{2} \mathrm{Cl}_{2}(50 \mathrm{~mL})$ is hydrolyzed according to the procedure with $\underline{\mathbf{3 c}}$. Dimeric 2-hydroxycyclohexanone $(2.8 \mathrm{~g}, 62 \%)$ is obtained as white powder, m.p. $112^{\circ} \mathrm{C}$. d) Addition of $\underline{\mathbf{2 c}}$ to the C,C double bond of $\underline{\mathbf{3 c}}$ affording 2-methoxy-1,2,3-tris(methoxycarbonyloxy)cyclohexane $(\underline{\mathbf{8}})$ : A solution of $\underline{\mathbf{2 c}}(0.125 \mathrm{~mol})$ in $\mathrm{CH}_{2} \mathrm{Cl}_{2}(250 \mathrm{~mL})$ is added dropwise under stirring to a mixture of $\underline{\mathbf{2 c}}(23.3 \mathrm{~g}, 0.125 \mathrm{~mol})$ and $\mathrm{CH}_{2} \mathrm{Cl}_{2}(20 \mathrm{~mL})$ maintained under gentle reflux in a bath of $50^{\circ} \mathrm{C}$. Stirring is continued for $36 \mathrm{~h}$ and traces of non-consumed peroxide are destroyed by addition of a catalytical amount of cuprous chloride (3g). The reaction mixture is filtered and $\mathrm{CH}_{2} \mathrm{Cl}_{2}$ is removed in a rotary evaporator. The oily residue is dissolved in a few $\mathrm{mL}$ of ether and stored for $2 \mathrm{~d}$ at $-20^{\circ} \mathrm{C}$. The formed crystals are isolated by suction, recrystallized from ether and dried in a desiccator; colorless crystals of $\underline{\mathbf{8}}$ are obtained, $25.6 \mathrm{~g}$ $(60 \%)$, m.p. $131.7^{\circ} \mathrm{C}$. For decarboxylation, $\underline{\mathbf{8}}(1.5 \mathrm{~g}, 4.5 \mathrm{mmol})$ is dissolved in a mixture of $\mathrm{CH}_{2} \mathrm{Cl}_{2}(60 \mathrm{~mL})$ and absolute methanol $(5 \mathrm{~mL})$. The solution is refluxed for $4 \mathrm{~d}$ and the solvent is removed as before. The oily residue crystallized after addition of ether (ca. $1 \mathrm{~mL}$ ); colorless crystals of 2,2-dimethoxy-1,3-bis-(methoxycarbonyloxy) cyclohexane (9) are obtained, 1.29g (98\%), m.p. $131^{\circ} \mathrm{C}$ (ether).

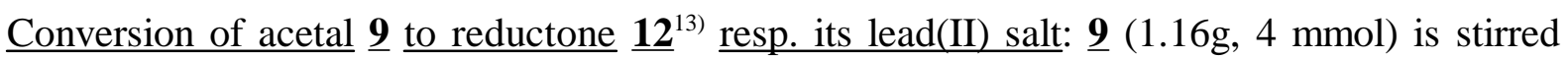
with a solution of $\mathrm{KOH}(0.5 \mathrm{~g}, 9 \mathrm{mmol})$ in water $(30 \mathrm{~mL})$ and methanol $(20 \mathrm{~mL})$ for $24 \mathrm{~h}$ at $50^{\circ} \mathrm{C}$. The resulting yellow solution is extracted with $\mathrm{CHCl}_{3}$, the organic phase is dried with $\mathrm{MgSO}_{4}$ and the solvent is evaporated i. vac. in a rotary evaporator; the oily residue is crystallized from a few $\mathrm{mL}$ of dry ether, affording colorless crystals of 1,3-dihydroxy2,2-dimethoxycyclohexane (10)$), 0.65 \mathrm{~g}(92 \%)$, m.p. $113.6^{\circ} \mathrm{C}$ (ether). $\underline{\mathbf{1 0}}(0.25 \mathrm{~g}, 1.4 \mathrm{mmol})$ in absolute $\mathrm{CH}_{2} \mathrm{Cl}_{2}(10 \mathrm{~mL})$ is added to a vigorously stirred suspension of pyridinium chlorochromate $(0.4 \mathrm{~g}, 1.8 \mathrm{mmol})$ in absolute $\mathrm{CH}_{2} \mathrm{Cl}_{2}(30 \mathrm{~mL})$ and the mixture is stirred for $16 \mathrm{~h}$ at R.T. Silica gel $(5 \mathrm{~g})$ is added and the mixture is filtered and evaporated. Crude 2,2-dimethoxy-3-hydroxycyclohexanone (11) is obtained as a yellow oil, $0.15 \mathrm{~g}(61 \%)$, which is directly hydrolyzed to $\underline{\mathbf{1 2}}$ by heating with $6 \mathrm{~N}$ hydrochloric acid $(10 \mathrm{~mL})$ for $10 \mathrm{~min}$ to $80^{\circ} \mathrm{C}$; formation of reductone $\underline{\mathbf{1 2}}^{13 a)}$ is proved by a positive coloration with methanolic ferric chloride (blue color) as well as by discoloration of Tillmans' reagent ${ }^{13 \mathrm{~b})}$. Addition of excess lead(II) 
acetate trihydrate $(0.5 \mathrm{~g}, 1.3 \mathrm{mmol})$ precipitates its lead chelate, $0.2 \mathrm{~g}(75 \%)$, insoluble in water.

Table 3: Spectral data of compounds obtained from conversions of $\underline{\mathbf{3 c}}$ (cf. Scheme 3) and $\underline{\mathbf{1 b}}$

\begin{tabular}{|c|c|c|c|c|c|}
\hline Product & & $v(\mathrm{cn}$ & & ${ }^{1} \mathrm{H}$ NMR, $\delta$ & ${ }^{13} \mathrm{C}$ NMR, $\delta$ \\
\hline$\underline{5}$ & \begin{tabular}{l|}
$\mathrm{C}=\mathrm{C}$ \\
1585 \\
1650
\end{tabular} & $\mathrm{C}=\mathrm{O}$ & $\mathrm{OH}$ & $\begin{array}{l}2.16\left(\mathrm{~m}, 4 \mathrm{H}, 2 \mathrm{CH}_{2}\right) ; 3.62\left(\mathrm{~s}, 3 \mathrm{H}, \mathrm{OCH}_{3}\right) ; \\
4.75(\mathrm{~m}, 1 \mathrm{H},=\mathrm{CH}-) ; 6.00(\mathrm{~m}, 2 \mathrm{H} \\
-\mathrm{CH}=\mathrm{CH}-)\end{array}$ & \\
\hline$\underline{6 c}$ & & $\begin{array}{l}1715 \\
1745\end{array}$ & & $\begin{array}{l}2.05\left(\mathrm{~m}, 8 \mathrm{H}, 4 \mathrm{CH}_{2}\right) ; 3.92(\mathrm{~s}, 3 \mathrm{H}, \\
\left.\mathrm{CO}_{2} \mathrm{CH}_{3}\right) ; 5.14(\mathrm{~m}, 1 \mathrm{H}, \mathrm{CH}-\mathrm{O})\end{array}$ & \\
\hline$\underline{8}$ & & 1755 & & $\begin{array}{l}\left.\text { 1.42-1.54 (m, } 1 \mathrm{H}, \mathrm{CH} \text { of } \mathrm{CH}_{2}\right) ; 1.79-1.95 \\
\left(\mathrm{~m}, 5 \mathrm{H}, 2 \mathrm{CH}_{2}+\mathrm{CH} \text { of } \mathrm{CH}_{2}\right) ; 3.57(\mathrm{~s}, 3 \mathrm{H}, \\
\left.\mathrm{OCH}_{3}\right) ; 3.78\left(\mathrm{~s}, 3 \mathrm{H}, \mathrm{CO}_{2} \mathrm{CH}_{3}\right) ; 3.79(\mathrm{~s}, \\
\left.6 \mathrm{H}, 2 \mathrm{CO}_{2} \mathrm{CH}_{3}\right) ; 5.45-5.48(\mathrm{~m}, 2 \mathrm{H} \\
2 \mathrm{CH}-\mathrm{O})\end{array}$ & $\begin{array}{l}\text { 17.6, } 27.4\left(2 \mathrm{CH}_{2}\right) ; 52.0\left(\mathrm{OCH}_{3}\right) ; \\
\text { 54.4, } 54.8\left(2 \mathrm{CO}_{2} \mathrm{CH}_{3}\right) ; 75.0(\mathrm{CH}-\mathrm{O}) ; \\
102.8\left(\mathrm{C}_{\text {quart. }}\right) ; 152.0,154.8(2 \mathrm{C}=\mathrm{O})\end{array}$ \\
\hline$\underline{9}$ & & 1750 & & $\begin{array}{l}1.56-1.95\left(\mathrm{~m}, 6 \mathrm{H}, 3 \mathrm{CH}_{2}\right) ; 3.24-3.28(2 \mathrm{~s} \\
6 \mathrm{H}, 2 \mathrm{OCH}) ; 3.78\left(\mathrm{~s}, 6 \mathrm{H}, 2 \mathrm{CO}_{2} \mathrm{CH}_{3}\right) ; 4.95 \\
(\mathrm{~m}, 2 \mathrm{H}, \mathrm{CH}-\mathrm{O})\end{array}$ & $\begin{array}{l}14.9,27.1\left(2 \mathrm{CH}_{2}\right) ; 48.7\left(\mathrm{OCH}_{3}\right) ; 54.7 \\
\left(\mathrm{CO}_{2} \mathrm{CH}_{3}\right) ; 73.5(\mathrm{CH}-\mathrm{O}) ; 96.8 \\
\left(\mathrm{C}_{\text {quart. }}\right) ; 155.2(\mathrm{C}=\mathrm{O})\end{array}$ \\
\hline$\underline{10}$ & & & 3340 & $\begin{array}{l}1.07-2.11\left(\mathrm{~m}, 6 \mathrm{H}, 3 \mathrm{CH}_{2}\right) ; 3.1(\mathrm{~d}, \mathrm{~J}=6.6 \\
\mathrm{Hz}, 2 \mathrm{H}, \mathrm{OH}) ; 3.20,3.38\left(2 \mathrm{~s}, 6 \mathrm{H}, 2 \mathrm{OCH}_{3}\right) ; \\
3.86-4.11(\mathrm{~m}, 2 \mathrm{H}, 2 \mathrm{CH})\end{array}$ & \\
\hline 11 & & 1750 & 3040 & $\begin{array}{l}1.6-2.9\left(\mathrm{~m}, 6 \mathrm{H}, 3 \mathrm{CH}_{2}\right) ; 3.23(\mathrm{~s}, 1 \mathrm{H}, \mathrm{OH}) \\
3.36-3.51\left(\mathrm{~m}, 6 \mathrm{H}, 2 \mathrm{OCH}_{3}\right) ; 4.20-4.36 \\
(\mathrm{~m}, 1 \mathrm{H}, \mathrm{CH})\end{array}$ & \\
\hline$\underline{3 d}$ & 1670 & 1750 & & $\begin{array}{l}0.25\left(\mathrm{~s}, 9 \mathrm{H}, \mathrm{SiMe}_{3}\right) ; 1.4-2.1(\mathrm{~m}, 6 \mathrm{H}, \\
\left.3 \mathrm{CH}_{2}\right) ; 4.78\left(\mathrm{~s}, 3 \mathrm{H}, \mathrm{CO}_{2} \mathrm{CH}_{3}\right) ; 4.95-5.1 \\
(\mathrm{~m}, 2 \mathrm{H}, 2 \mathrm{CH})\end{array}$ & \\
\hline
\end{tabular}

6-Methoxycarbonyloxy-1-trimethylsiloxy-1-cyclohexene (3d): A solution of $\underline{\mathbf{2 c}}$ in $\mathrm{CH}_{2} \mathrm{Cl}_{2}(0.2$ mol) is dropped to a boiling mixture of enol silylether $\underline{\mathbf{1 b}}^{20)}(37.5 \mathrm{~g}, 0.22 \mathrm{~mol})$ and absolute $\mathrm{CH}_{2} \mathrm{Cl}_{2}(100 \mathrm{~mL})$. After continuous reflux for $14 \mathrm{~h}$ peroxide $\underline{\mathbf{2 c}}$ is quantitatively consumed.

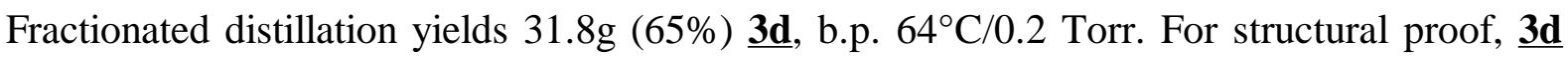
(24.4g, $0.1 \mathrm{~mol})$ in $\mathrm{CH}_{2} \mathrm{Cl}_{2}(100 \mathrm{~mL})$ is refluxed for $30 \mathrm{~min}$ with a mixture of conc. hydrochloric acid $(25 \mathrm{~mL})$ and water $(25 \mathrm{~mL})$. Usual work-up yields $13.8 \mathrm{~g}(80 \%) \underline{\mathbf{6 c}}$, m.p. $65^{\circ} \mathrm{C}$ (ethyl acetate).

$\underline{\text { 1:1-additions of }} \underline{\mathbf{2 c}} \underline{\text { to aldehyde enol ethers }} \underline{\mathbf{1 6}} \underline{\mathbf{1 8}}$. a) A solution of $\underline{\mathbf{2 c}}$ in $\mathrm{CH}_{2} \mathrm{Cl}_{2}(0.1 \mathrm{~mol})$ is dropped to a solution of i-butyl vinyl ether $(\underline{\mathbf{1 6}})(10.0 \mathrm{~g}, 0.1 \mathrm{~mol})$ in absolute $\mathrm{CH}_{2} \mathrm{Cl}_{2}(50 \mathrm{~mL})$, stirred in a bath of $50^{\circ} \mathrm{C}^{25}$. Stirring at $50^{\circ} \mathrm{C}$ is continued for $36 \mathrm{~h}$, nonconverted $\underline{\mathbf{2 c}}$ is decomposed by addition of a catalytic amount of cuprous chloride (3g). After filtration and distillation 1,2-bis(methoxycarbonyloxy)-1-i-butoxy-ethane (19) is obtained as a colorless oil, $19.5 \mathrm{~g}(78 \%)$, b.p. $76^{\circ} \mathrm{C} / 10^{-3}$ Torr. b) As before, but in a bath of $70^{\circ} \mathrm{C}, 2,3$-dihydrofuran $\underline{\mathbf{1 7}}$ $(6 \mathrm{~g}, 86 \mathrm{mmol})$ reacts with equimolar amount of $\underline{\mathbf{2 c}}$ yielding $\underline{\mathbf{2 0}}$ (11.9 g $(63 \%, 55: 45$ mixture of 
isomers)) as a colorless, viscous oil, b.p. $92^{\circ} \mathrm{C} / 10^{-3}$ Torr. c) Correspondingly, but in a bath of $80^{\circ} \mathrm{C}, 2,3$-dihydropyran $(8.41 \mathrm{~g}, 0.1 \mathrm{~mol})$ reacts with equimolar amount of $\underline{\mathbf{2 c}}$ yielding $\underline{\mathbf{2 1}}$ (10.1 $\mathrm{g}(43 \%, 50: 50$ mixture of isomers $))$ as a pale-yellow viscous oil, b.p. $101^{\circ} \mathrm{C} / 10^{-3}$ Torr.

Table 4: 1:1 addition products $\underline{\mathbf{1 9}} \underline{\underline{\mathbf{2 1}}}$ of $\underline{\mathbf{2 c}}$ to aldehyde enol ethers $\underline{\mathbf{1 6}} \underline{\mathbf{1 8}}$

\begin{tabular}{|c|c|c|c|}
\hline Product & $\mathrm{IR}, \mathrm{v}\left(\mathrm{cm}^{-1}\right)$ & ${ }^{1} \mathrm{H}$ NMR, $\delta$ & ${ }^{13} \mathrm{C}$ NMR, $\delta$ \\
\hline$\underline{19}$ & $\begin{array}{l}\mathrm{C}=\mathrm{O} \\
1768\end{array}$ & $\begin{array}{l}0.9,0.91\left(\mathrm{~d}, 6 \mathrm{H}, 2 \mathrm{CH}_{3}\right) ; 1.81-1.93(\mathrm{~m}, 1 \mathrm{H} \\
\mathrm{CH}) ; 3.36-3.62\left(\mathrm{~m}, 2 \mathrm{H}, \mathrm{CH}_{2}-\mathrm{O}\right) ; 3.80,3.81 \\
\left(2 \mathrm{~s}, 6 \mathrm{H}, 2 \mathrm{OCH}_{3}\right) ; 4.24\left(\mathrm{dd}, 2 \mathrm{H}, \mathrm{CH}_{2}-\mathrm{O}-\mathrm{C}=\mathrm{O}\right) ; \\
5.87(\mathrm{t}, 1 \mathrm{H}, \mathrm{O}-\mathrm{CH}-\mathrm{O}-\mathrm{C}=\mathrm{O})\end{array}$ & $\begin{array}{l}19.4\left(\mathrm{CH}_{3}\right) ; 28.3(\mathrm{CH}) ; 54.8\left(\mathrm{OCH}_{3}\right) ; \\
66.5\left(\mathrm{OCH}_{2}\right) ; 76.5\left(\mathrm{CH}_{2}-\mathrm{O}-\mathrm{C}=\mathrm{O}\right) ; 97.9 \\
(\mathrm{O}-\mathrm{CH}-\mathrm{O}-\mathrm{C}=\mathrm{O}) ; 154.8,155.0(\mathrm{C}=\mathrm{O})\end{array}$ \\
\hline$\underline{20}$ & 1750 & $\begin{array}{l}\left.\text { 2.10-2.22 (m, 2H, } \mathrm{CH}_{2}\right) ; 2.37-2.45(\mathrm{~m}, 2 \mathrm{H}, \\
\left.\mathrm{CH}_{2}\right) ; 3.798,3.807,3.813,3.824(4 \mathrm{~s}, 12 \mathrm{H}, \\
\left.4 \mathrm{OCH}_{3}\right) ; 3.98-4.04(\mathrm{q}, 1 \mathrm{H}, \underline{\mathrm{H}}-\mathrm{CH}-\mathrm{O}) ; \\
4.16-4.23(\mathrm{~m}, 3 \mathrm{H}, 3 \mathrm{H}-\mathrm{CH}-\mathrm{O}) ; 5.06-5.11(\mathrm{~m}, \\
\left.1 \mathrm{H}, \mathrm{CH}_{\mathrm{ax}}-\mathrm{O}\right) ; 5.13-5.15\left(\mathrm{dd}, 1 \mathrm{H}, \mathrm{CH}_{\mathrm{ax}}-\mathrm{O}\right) ; \\
6.13\left(\mathrm{~s}, 1 \mathrm{H}, \mathrm{O}-\mathrm{CH}_{\mathrm{ax}}-\mathrm{O}\right) ; 6.21-6.22(\mathrm{~d}, \mathrm{~J}=4.1 \\
\left.\mathrm{Hz}, 1 \mathrm{H}, \mathrm{OCH}_{\mathrm{eq}}-\mathrm{O}\right)\end{array}$ & $\begin{array}{l}26.7,28.8\left(\mathrm{CH}_{2}\right) ; 54.6,54.7,54.9 \\
\left(\mathrm{CH}_{3} \mathrm{O}\right) ; 66.1,68.1\left(\mathrm{CH}_{2}-\mathrm{O}\right) ; 75.2,80.0 \\
96.6,102.3(\mathrm{CH}-\mathrm{O}) ; 154.2,154.6,154.8 \\
(\mathrm{C}=\mathrm{O})\end{array}$ \\
\hline$\underline{21}$ & 1770 & $\begin{array}{l}1.51-2.12\left(\mathrm{~m}, 8 \mathrm{H}, 2 \mathrm{CH}_{2}-\mathrm{CH}_{2}\right) ; 3.7(\mathrm{~m}, 2 \mathrm{H}, \\
\left.2 \mathrm{OCH}-\mathrm{H}_{\mathrm{ax}}\right) ; 3.78,3.80,3.81,3.82(4 \mathrm{~s}, 12 \mathrm{H}, \\
\left.4 \mathrm{OCH}_{3}\right) ; 3.92\left(\mathrm{~m}, 2 \mathrm{H}, 2 \mathrm{OCH}-\mathrm{H}_{\mathrm{eq}}\right) ; 4.64(\mathrm{q}, \\
\left.1 \mathrm{H}, \mathrm{CH}_{\mathrm{ax}}-\mathrm{O}\right) ; 4.76\left(\mathrm{~m}, 1 \mathrm{H}, \mathrm{CH}_{\mathrm{eq}}-\mathrm{O}\right) ; 5.80(\mathrm{~d}, \\
\left.\mathrm{J}_{\mathrm{ae}}=2.9 \mathrm{~Hz}, \mathrm{O}-\mathrm{CH}_{\mathrm{eq}}-\mathrm{O}\right) ; 6.06\left(\mathrm{~d}, \mathrm{~J}_{\mathrm{ee}}=3.1 \mathrm{~Hz},\right. \\
\left.1 \mathrm{H}, \mathrm{O}-\mathrm{CH}_{\mathrm{eq}}-\mathrm{O}\right)\end{array}$ & $\begin{array}{l}14.7,18.2,18.6\left(\mathrm{CH}_{2}\right) ; 49.2,49.4 \\
\left(\mathrm{OCH}_{3}\right) ; 55.6,57.0\left(\mathrm{OCH}_{2}\right) ; 65.4,66.9 \\
(\mathrm{OCH}) ; 88.1,88.9(\mathrm{O}-\mathrm{CH}-\mathrm{O}) ; 149.1 \\
149.5149 .6(\mathrm{C}=\mathrm{O})\end{array}$ \\
\hline
\end{tabular}

We are indebted to Thomas Heisel for graphical arrangement of the manuscript

(1) a) Horner, L.; Winkelmann, E.H. Angew. Chem. 1959, 71, 349;

b) Roedig, A. in Methoden der Organischen Chemie (Houben-Weyl-Müller), 4. Aufl., Bd. 5/4, S. 221, Thieme, Stuttgart 1960;

c) Filler, R. Chem. Rev. 1963, $\underline{63}, 21$.

(2) Chanon, M.; Tobe, M.L. Angew. Chem. 1982, 94, 27; Int. Ed. Engl. 21, 1.

(3) Rawlinson, D.J.; Sosnovsky, G. Synthesis 1972, 1.

(4) Schank, K.; Felzmann, J.H.; Kratzsch, M. Chem. Ber. 1969, 102, 388.

(5) Schank, K.; Pack, W. Chem. Ber. 1969, 102, 1892.

(6) Schank, K.; Beck, H. unpublished; Beck, H., Diplomarbeit, Universität des Saarlandes, Saarbrücken 1983.

(7) a) Summary on bis-(alkoxycarbonyl) peroxides: Edl, W.; Kropf, H. in Methoden der Organischen Chemie (Houben-Weyl), 4. Aufl., Bd. E13 (Herausg. Kropf, H.), S. 918, Thieme, Stuttgart 1988; 
b) Bouillon, G.; Lick, C.; Schank, K. in The Chemistry of Functional Groups, Peroxides (Ed. S. Patai), Chapt. 10, p. 279, Wiley-Interscience 1983;

c) Aromatic oxygenation with peroxydicarbonate: Refs. of Kurz, M.E.; Kovacic, P.; and co-workers 1968-1974 cf. Minisci, F.; Citterio, A. in Advances in Free-Radical Chemistry, Vol. $\underline{6}$ (Ed. Williams, G.H.), p. 65, Heyden and Son, London, Philadelphia, Rheine 1980, on p. 104.

(8) DBE's of selected organic peroxides: $\mathrm{H}_{3} \mathrm{CO}-\mathrm{OCH}_{3} 36 \mathrm{kcal} / \mathrm{mol} ; \mathrm{H}_{3} \mathrm{CO}_{2} \mathrm{CO}-\mathrm{OCO}_{2} \mathrm{CH}_{3}$ $30 \mathrm{kcal} / \mathrm{mol} \mathrm{cf}$. CRC Handbook of Chemistry and Physics, 50 ${ }^{\text {th }}$ Edit. 1969-1970, F-163.

(9) Acceleration of diacyl peroxide decompositions by electron donors: Walling, C. J. Am. Chem. Soc. 1980, 102, 6854.

(10) SET-catalyzed alcohol additions to enol ether $\underline{\mathbf{1 8}}$. a) by means of DDQ: Tanemura, K.; Horaguchi, T.; Suzuki, T. Bull. Chem. Soc. Jpn. 1992, $\underline{65}, 304$; b) by means of CAN $\left(\mathrm{Ce}\left(\mathrm{NH}_{4}\right)_{2}\left(\mathrm{NO}_{3}\right)_{6}\right)$ : Maity, G.; Roy, S.C.; Synth. Commun. 1993, 23, 1667.

(11) Rubottom, G.M. et al. Synth. Commun. 1976, $\underline{6}$, 59; J. Org. Chem. 1976, 41, 1673; Tetrahedron 1983, 39, 861; J. Org. Chem. 1983, $\underline{48}, 4940$.

(12) In nucleophile-electrophile interactions enol ethers and enol silylethers like $\underline{\mathbf{1 a}}$ and $\underline{\mathbf{1 b}}$ should show comparable reaction rates: Mayr, H.; Patz, M. Angew. Chem. 1994, 106 , 990, on p. 995-6; the considerably slower reaction rate of silylether $\underline{\mathbf{1 b}}$ compared with 1a is assumed to be the consequence of an alternative reaction mechanism.

(13) a) Schank, K.; Wessling, D. Liebigs Ann. Chem. 1967, 710, 137.

b) For a review cf. Schank, K. Synthesis 1972, 176.

(14) Sawaki, Y. in The Chemistry of Hydroxyl, Ether and Peroxide Groups, Vol. 2, Supplement E (Ed. Patai, S.), Chapt. 11, p. 587, Wiley-Interscience 1993; cf. 7b).

(15) cf. a) "Ethylenic Compounds as Probes for the Study of Donor-Acceptor Interactions": Todres, Z.V. Tetrahedron Report No. 224, Tetrahedron 1987, 43, 3839;

b) Olefin radical cations by means of peroxydisulfate: Clerici, A.; Minisci, F.; Ogawa, K.; Surzur, J.M. Tetrahedron Lett. 1978, 1149.

(16) "Alkenes react with diacyl peroxides via an SET process": Fujimoto, K. in Organic Peroxides (Ed. Ando, W.), p. 378, Wiley-Interscience 1992.

(17) cf. Addition of DDQ to substituted enol ether benzofuran via CT-complex and geminate radical ion pair: Tanemura, K.; Suzuki, T.; Horaguchi, T. Bull. Chem. Soc. Jpn. 1993, $\underline{66}, 1235$. 
(18) Wohl, R.A. Synthesis 1974, 38.

(19) Moell, N.; Schank, K. Chem. Ber. 1969, 102, 71.

(20) Taniguchi, Y.; Inanaga, J.; Yamaguchi, M. Bull. Chem. Soc. Jpn. 1981, 54, 3229.

(21) Stain, J.; Bissinger, W.-E.; Dial, W.R.; Rudoff, H.; DeWitt, B.J.; Stevens, H.C.; Langston, J.H. J. Am. Chem. Soc. 1950, 72, 1254; cf. 7a, 7b.

(22) Fritz, E.; Langhals, H.; Mergelsberg, I. Chem. Ber. 1980, 113, 3662.

(23) Stevens, C.L.; Tazuma, J. J. Am. Chem. Soc. 1954, 76, 715.

(24) Frimer, A.A. J. Org. Chem. 1977, 42, 3194.

(25) Heating in a bath of $80^{\circ} \mathrm{C}$ leads to decarboxylation yielding the corresponding i-butyl methyl acetal of methoxycarbonyloxyacetaldehyde in 57\%; on the other hand, the same acetal is obtained by thermal decarboxylation of neat 21a at $130-140^{\circ} \mathrm{C}$ for $2 \mathrm{~h}$ in $75 \%$ yield, b.p. $50-52^{\circ} \mathrm{C} / 10^{-3}$ Torr. 